\title{
Ongoing Substance Use
}

National Cancer Institute

\section{Source}

National Cancer Institute. Ongoing Substance Use. NCI Thesaurus. Code C162330.

An indication or description that substance usage is continuing. 